\title{
DECOLONIZING STRAIGHT TEMPORALITY THROUGH GENRE TROUBLE IN EDWIDGE DANTICAT'S THE FARMING OF BONES
}

\author{
Eliana de Souza Ávila* \\ Universidade Federal de Santa Catarina
}

\begin{abstract}
Framing genre trouble (McKenzie 1998) as a decolonial methodology, this paper considers the relevance of Edwidge Danticat's The Farming of Bones (1998) for reading migrant texts against the grain of straight temporality which sustains the coloniality of power (Lugones 2007). Scrutinizing historiographic suppression, Danticat's migrant text interrupts the chrononormative portrayal of the Trujillo genocide of Haitian workers in the Dominican Republic as a reality pertaining to an obsolete past and to the geocultural margins alone. Read in the aftermath of the testimonio controversy, it may thus decenter the ongoing deflection of attention from Rigoberta Menchús impact on the geocultural structures that sanction ongoing military intervention and genocide by refocusing on historiography as a terrain of relentless decolonial contestation rather than prescriptive narrative closure.

Keywords: Migrant text; Edwidge Danticat; genre trouble; Haitian literature; decolonial chronopolitics.
\end{abstract}

\section{Resumo:}

Partindo do questionamento das fronteiras de gênero textual (McKenzie 2006) como metodologia descolonial, este artigo considera a relevância de The Farming of Bones de Edwidge Danticat (1998) para descolonizar a cronopolítica linear do atraso na qual estão necessariamente imbricadas as narrativas de migração. Ao narrar a supressão historiográfica do genocídio de trabalhadores haitianos na República Dominicana, Danticat expõe a cronopolítica normativa que relega seu significado a um tempo obsoleto e exclusivo à realidade das margens geoculturais. Na esteira da controvérsia dos anos 2000 sobre o gênero testimonio, o texto migrante de Danticat tende a reconduzir a discussão iniciada por Rigoberta Menchú contra as estruturas geoculturais coniventes com a continuidade do militarismo e do genocídio, capturando a historiografia como um terreno de contestação descolonial.

Palavras-chave: Texto migrante; Edwidge Danticat; fronteiras de gênero textual; literatura haitiana; cronopolítica descolonial.

What we think of as 'perception' is always already an inscription.

Gayatri Chakravorty Spivak, "Translator's Preface”

To be implicated in the relations of power, indeed, enabled by the relations of power that the "I" opposes is not, as a consequence, to be reducible to their existing forms. Judith Butler, Bodies that Matter

For people of color have always theorized-but in forms quite different from the Western form of abstract logic. And I am inclined to say that our theorizing (and I intentionally use the verb rather than the noun) is often in narrative forms, in the stories we create, in riddles and proverbs, in the play with language, since dynamic rather than fixed ideas seem more to our liking. How else have we managed to survive with such spiritedness the assault on our bodies, social insitutions, countries, our very humanity? Barbara Christian, "The Race for Theory"

\section{Introduction: Coloniality of Power and Chronopolitics}

Migration is clearly thought of as a spatial event. However, it is also taken for granted as an inherent shift from the past to the present, from a pre-modern

\footnotetext{
* Eliana de Souza Ávila is Associate Professor of Literary and Cultural Studies at Universidade Federal de Santa Catarina, where she conducts various teaching, research, and outreach activities. Ávila has worked at analyzing and elaborating queer perspectives at the intersection of decolonization, counter-ableism, and epistemic translation studies in dialog with social movements and artistic practices. She currently coordinates the Research Group Queer Perspectives in Debate (CNPq/UFSC). E-mail: elavila.ufsc@gmail.com
} 
to a post-modern temporality. This mapping of an anachronic or obsolete other is a crucial component of what Aníbal Quijano has termed the coloniality of power: "a conception of humanity according to which [from the colonial period on] the global population was differentiated into inferior and superior, irrational and rational, primitive and civilized, traditional and modern" (Lugones 192). ${ }^{1}$ Following Quijano, Nelson Maldonado-Torres makes the point that coloniality refers not to the takeover of sovereignty, as does colonialism, but, rather, to

long-standing patterns of power that emerged as a result of colonialism, but that define culture, labor, intersubjective relations, and knowledge production well beyond the strict limits of colonial administrations. Thus, coloniality survives colonialism. It is maintained alive in books, in the criteria for academic performance, in cultural patterns, in common sense, in the self-image of peoples, in aspirations of self, and so many other aspects of our modern experience. (243)

Considering Quijano's argument that the perpetuation of racism is at the roots of the coloniality of power, Michel-Rolph Trouillot (1995) scrutinizes the latter's inception in the wake of colonialism by asking how the Haitian Revolution could be undermined just two years after the discourses of human equality, fraternity, and liberty had been won for the French Revolution. For Trouillot, as for both Walter Mignolo and Michael Ennis following him, those liberal discourses that consolidated Europe and the bourgeois paradigm of the nation were only able to ignore the independence of the first Black republic-as well as the intellectual production alongside the Amerindian rebellions from the sixteenth century on-because the eurocentric understanding of the rights of man (sic) "had been thought in a world where the invisible matrix' was white, that is, composed fundamentally of white citizens and not Indians or Negroes" (Mignolo \& Ennis 42). Haitian underdevelopment was then both produced and naturalized as a chronic yet profitable by-product of a supposedly anachronic state of being: a realm of lack, deficit or deficiency proper to formerly colonized regions (Africa, the Caribbean, Latin America and Asia) rather than fabricated by colonial power. ${ }^{2}$ Hence the coloniality of power relies on the reinforcement of a normative chronopolitics-a developmentalist master narrative by which, as Elizabeth Freeman puts it, "Western 'modernity' ... has represented its own forward movement against a slower premodernity figured as brown-skinned, feminine, and erotically perverse" $(57){ }^{3}$

Understood not only as narratives of migration but also as texts performing the migration of such narratives, migrant texts speak from and to distinct geocultural spaces in historical relation to the centers of global power. They shape and constitute the very structures of coloniality within which they must circulate-and which they often transform. While normative chronopolitics fabricates a linear progression from a primitive, underdeveloped past to a civilized, developed present, migrant texts are legitimized in discourse only as they anachronize that past within interlocking discourses warranting its (and their) obliteration: such texts must come from a space-time described either as virgin, to be developed for profit pending on the penetration of capital, or as hopelessly defiled and left behind history. These gendered tropes of straight temporality pervade migrant texts and their racialization, even as they straddle established geocultural perspectives in order to re-negotiate and re-signify them. ${ }^{4}$

\section{Cafecitos and dulce de leche?}

Edwidge Danticat's migrant fiction foregrounds the asymmetrical geocultural and historiographic relations in which Caribbean narratives are written, published, and read. Her novels trace the migratory quest marked by the chronopolitical borders between Haiti and the Dominican Republic on the island of Hispaniola-and, by extension, between Hispaniola and the U.S. These pathways were first established during the U.S. military occupation of Haiti (from 1915 to 1934) and the Dominican Republic (from 1916 to 1924). Repressing alliances between the twin nations, the occupation fed hostility across the Haitian-Dominican border, itself an emblem of the political instability invested in renewing 
economic and military intervention in the region. Setting a historical pattern which had reached the center of the debate on global politics by the time Danticat was writing The Farming of Bones (1998), the U.S. removed its troops from Haiti in 1934-but not until it had secured a set of institutional measures. These included the enforcement of a new constitution legalizing both the expropriation of Haitian land by foreigners (mostly in the business of importing and exporting Caribbean sugar-cane) alongside various separatist policies (which had been unconstitutional prior to the U.S. occupation), thus further dividing the twin nations. ${ }^{5}$

The Farming of Bones is a fictional metatestimonio of the 1937 massacre of 20,000 to 40,000 Haitian migrants by the army of Dominican dictator Rafael Trujillo as told by the adult Amabelle Desir. ${ }^{6}$ As a child, Amabelle had witnessed her parents drowning as they crossed the river from Haiti, and was taken in by an upper-class Dominican family to be raised as an unpaid domestic servant on their estate near the borderland plantation town of Alegría. Danticat's novel testimonio focuses on the "sanctioned ignorance" of Haitian historiography in the context of continued U.S. financial support for the Trujillo administration in the aftermath of the slaughter, its historiographic suppression clearly echoing the obliteration of Haitians' protagonism in the 1791-1803 revolution-clashing with the inception of the enlightenment and its establishment of modernity's eurocentric chronopolitics in the wake of colonialism. ${ }^{8}$

Scholarship has emphasized the relevance of The Farming of Bones as revisionary historiography (Shemak 2002; Ink 2004; Rohrtleitner 2011; Tegmark 2012; Misraki-Barak 2013), postmodern historiographic metafiction (Tegmark 2012), and as performing specific subgenres of testimonio-such as immigrant testimonio (Kaussen 2008), fictional testimonio (Shemak 2002), metatestimonio (Segura-Rico 2009), and trauma testimonio (Sesnik 2006; Caminero-Santangelo 2009; Misraki-Barak 2013). April Shemak situates Danticat's novel as a timely counterpoint to another fictional testimonio, the canonical In the Time of the Butterflies by Julia Alvarez (1995). Significantly, Shemak's objection to Alvarez's novel is that its portrayal of historical events reproduces a hegemonic Dominican view over Haiti, for it makes "little mention of Haitian oppression or the 1937 massacre of 20,000 Haitians by Trujillo's army". Associating the widespread acclaim for Alvarez's novel to its reproduction of "a nationalist history that ignores class and racial divisions within the nation" and within Hispaniola itself, Shemak foregrounds the relevance of Danticat's project to re-memember Haitian perspectives on the genocide and on its normalized obliteration from regional and global history (84). This decolonial standpoint is the focus of testimonial writing, understood as an effective challenge to the silencing of subaltern narratives.

\section{The Farming of Bones in the Context of the Latin American Testimonio}

The genre of Latin American testimonio emerged in its modern form in the 1960s, 70s, and 80s-a period when increasing numbers of scholars became attuned to the inextricable relations between knowledge and power, and therefore to the urgency of opening up the literary canon to counter-hegemonic knowledges. As George Yúdice recalls, "it is not until after the creation of a literary award for testimonial literature by one of the Americas' major cultural institutions, Casa de las Américas, that the genre, with its attendant emphasis on the marginal and the popular, is recognized as such" (25-26).

Initially associated with anti-slavery and revolutionary movements in Central and South America, the testimonio has been defined as a genre that "prescribes the sociopolitical function of denouncing official representation of traumatic events in history" (Unnold 77). Yúdice characterizes it as the portrayal of the experience of a witness as "an agent (rather than a representative) of a collective memory and identity [...] in the cause of denouncing a present situation of exploitation and oppression or in exorcising and setting aright official history" (17). Significantly, writers and critics have long stressed that the testimonio is necessarily mediated by the narrative persona-as are all genres, according to the basic literary tenet that the narrative persona is distinct from that of the author. ${ }^{10}$ In this sense, the testimonio is not so much a referential discourse of identity but, rather, a performative act, 
not so much a representation of a referent $[\ldots]$ but a practice involved in the construction of such an entity. That is, testimonial writing is first and foremost an act, a tactic by means of which people engage in the process of selfconstitution and survival $[. .$.$] a way of using$ narrative discourse whose function is not solely pragmatic (i.e., for the purposes of self-defense and survival) but just as significantly aesthetic (insofar as the subjects of the testimonial discourse rework their identity through the aesthetic), though that aesthetic does not usually correspond to the definitions of the literary as legitimized by dominant educational, publishing, and professional institutions. (19)

While the first testimonio in its modern Latin American version is most often attributed to Biografía de un cimarrón (Montejo and Barnet 1966), scholars have acknowledged that it actually extends back to 1960 with the publication, simultaneously in Brazil and in the U.S., of the diary of a favelada (slum-dweller), Carolina Maria de Jesus's Quarto de Despejo. ${ }^{11}$

After Montejo's biography, the most cited examples of Latin American testimonio are Se me permiten hablar (Barrios de Chungara and Viezzer 1978 [1977]) and Me llamo Rigoberta Menchú y así me nació la conciencia (Menchú and Burgos-Debray 1983). The latter, translated into English by Ann Wright as Rigoberta Menchú: An Indian Woman in Guatemala (1984), was the first to enter the canon, harnessing international public opinion towards ending military intervention in Guatemala. Rigoberta Menchú was awarded the Nobel Peace Prize in 1992 while also becoming a target for strident attacks by right-wing scholars adhering to the legacy of Reagan's repression of academic curricula against the efforts of anti-racist and feminist activists who, newly empowered by institutional shifts, had begun to challenge, change, and expand the canon. ${ }^{12}$

Kimberley Nance distinguishes between the early years of testimonio, "characterized by a near-euphoric celebration [mostly by academic supporters in the U.S.] of a poetics of solidarity among all concerned" (3), and the turn of this century, which saw what came to be called "the Rigoberta Menchú controversy." This was ignited by anthropologist David Stoll's attempt to demolish the impact of Menchú's narrative by indicting it for its lack of authenticity and its covert persuasive rhetoric-a debate that extended from Menchús testimonio to the entire genre. ${ }^{13}$ Like in other late twentieth-century fields of cultural critique which saw the crucial problematization of hegemonic discoursesas in feminist, postcolonial, poststructuralist and cultural studies -, the necessary politics of suspicion has too often surrendered entire fields of knowledge instead of changing, refining, and extending their critical reach. Indeed, the testimonio came close to its premature burial such that its contestatory potential has yet to be excavated and re-signified-toiled and harvested, as the title of Danticat's novel suggests. ${ }^{14}$

In the 60 s and throughout the 80 s the genre gained power amid the debates on the definitions of literary legitimacy and canon-revision. Already by the $90 \mathrm{~s}$, however, it was being celebrated as a spectacle of otherness, recontained and mapped onto a fixed ethnographic category that suppressed its troubling of the eurocentric institution of literature-in a nutshell, it was being tamed and reduced to what Graham Huggan (2001) would later call the postcolonial exotic. Already in 1993, in Against Literature, John Beverley had perceptively called attention to the fetichization of testimonio as it became institutionalized in ways that tended to confirm rather than decolonize geopolitical and literary truths as well as their suppression from within the literary establishment's version of literature itself. ${ }^{15}$

The controversy raised by Stoll may have seemed decisive in further entrenching the testimonio under the criteria of genre stability-not by celebrating its alterity this time, but by disqualifying it instead. As Norma Klahn argues,

\footnotetext{
Stoll had reduced otherness to sameness and used similar judgment tools in his (mis) reading rather than understanding the appeal of the narrative to human rights abuses that were foregrounding questions of ethics rather than accuracy. An understanding of colonialism's legacies could have rendered an ethical response to alterity. (44)
}

Whether Stoll's (mis)reading was "successful"-a term I use here with intentional ambivalence-is a 
question that has been re-opened for debate; various commentators have voiced "a general suspicion of motives and a profound pessimism regarding the genre's social possibilities" (Nance 5), whereas others defend a more complex rethinking of the arbitrary view that the era of the testimonio is over (Sanjínes 1996). These positions have been held not only by critics of coloniality but also by testimonio writers who have been reappropriating the debate by calling attention to the political potential of its genre trouble-its blurring of the boundaries between ethnography and literature, history and fiction, transparency and persuasive rhetoric. ${ }^{16}$ This revival of testimonio through genre trouble has complexified the controversy in order to problematize the authenticist and chronopolitical tools under which such migrant texts have been gauged. ${ }^{17}$

Although Stoll's campaign against Menchứs text could not trivialize the success of its appeal for international support against the genocide in Guatemala, a survey of the literature suggests that it had the effect of drastically trivializing the impact of testimonio towards changing the "literary can(n) on," much like a backlash. ${ }^{18}$ In his timely analysis of Stoll's argumentation, Arturo Arias contends that Stoll invested in the colonialist ideology that fixes both truth and strategic discourse as prerogatives of the Western subject alone. Indeed, Menchú's testimonio was dismissed for being both "not Western enough" in its concern with truth, because it privileged collective memory and subaltern solidarity over proof of evidence, and "too Western in her politics," in the sense that it was insufficiently "representative of what he judged to be authentic 'native' Maya thought" (86). In this light, Stoll implicitly indicts Menchús text for its genre trouble-it is neither personal autobiography nor collective politics, but both, and neither documentary nor fiction, but a challenge to these boundaries of normative knowledge which effectively overwrite the urgent task of changing history. ${ }^{19}$ As described by Arias, his text "has more in common with the protocol of the U.S. judicial system than with a self-aware anthropological project that values different discursive and cultural systems" (97).

Stoll's effort to stall Menchús impact on troubling the disciplinary boundaries between literature, ethnicity, and political history ironically exposed a broader colonial discourse in its anxiety to safeguard those boundaries anchored in the monocentric parameters of Western knowledge production. That such an effort confirms rather than undermines the continued urgency of revisiting the genre for the decolonial project cannot be overstated. Nevertheless, Stoll's argument was timely to the extent that it demystified the authenticist myth which has too often portrayed the testimonio as a pure text unmediated by contemporary geocultural relations and complex rhetorical strategies. Furthermore, and ironically, Stoll unwittingly helped to foreground the very politics of Latin American testimonio by significantly "contribut[ing] to the demise of the traditional role of the intellectual/artist as spokesperson for the 'voiceless"' (Yúdice 15). We will see in the next section that, read in the aftermath of the Stoll/Menchú controversy, Danticat's novel refocuses on whether and how genocide testimonials, as obliterated histories, can re-member geocultural knowledges and genres divided by chronopolitical boundaries.

\section{Genre Trouble in the novel testimonio The Farming of Bones}

In Romance languages, genre (genre in French, gênero in Portuguese, etc.) translates into English as both gender and genre. Playing on this doubling, the term genre trouble extends Judith Butler's concept of gender trouble (1990) to consider the ways in which the boundaries of genre, too, resonating in and from gender, are always already blurred. Considering the broad implications of queer politics to various contexts of knowledge and power, Jon McKenzie points out that

deconstructing the performativity of gender has everything to do with subverting not only the genders but also the genres [...]. As Jacques Derrida [and Avital Ronell show] in 'The Law of Genre' (1980), [...] the law or clause that genres cannot be mixed only emerges out of the law of the law of genre, the troubling clause that the mark of belonging does not belong, that property rights involve writs of impropriety (219). 
To trouble and queer genre, from an epistemic as much as an identitarian perspective, is to denaturalize the fixity of genre boundaries and the normative structures they strive to keep in place. In the case of testimonio, genre trouble seeks to denaturalize the chronopolitics of straight temporality which works to anachronize testimonio voices.

Considering that the critical history The Farming of Bones shows its pervasive association with the testimonio genre, it may be surprising that, as Shemak argues, Amabelle defers her own story of the massacre until only after 26 chapters out of 41 . My argument, however, is that a re-reading of this deferral today is strategic towards revitalizing the political effectiveness of the testimonio in the aftermath of the controversy raised by Stoll.

From the start, Danticat foregrounds Amabelle's reluctance to realize the political conflict between other Haitian migrants and the US-backed Dominican dictatorship. This reluctance is central to her decolonial text, since the deferral of the testimonio within the novel calls attention to the unspeakable relations withholding Haitian perspectives from the anglophone reader. As political scientist Howard Wiarda puts it,

For the Marine-created constabulary through which Trujillo rose to power, for the praise which congressmen, clerics, ambassadors, and other high officials showered upon him, for the aid given him, and for the close and friendly relationship which long existed between the two countries, the United States was often considered by many Dominicans to bear responsibility for the entire Trujillo era. $(192)^{20}$

The same could be said of Haitians in relation to the Dominican Republic, in terms of the dynamics of hierarchy operating internally on the island of Hispaniola under the sanction of the U.S.-a hierarchy perpetuated by the denial of those who, like Danticat's narrator well into the novel, are invested in naturalizing their relatively privileged position under patriarchal stability and in enacting the unreality of subaltern concerns, which are thus resubalternized.
This is the sense in which Amabelle is reluctant to believe that she should leave the supposed safety of the Dominican household to flee the genocide:

It couldn't be real. Rumors, I thought. There were always rumors, rumors of war, of land disputes, of one side of the island planning to invade the other. [...] This could not touch people like me, nor people like Yves, Sebastien, and Kongo who worked the cane fields. They were giving labor to the land. The Dominicans needed the sugar from the cane for their cafecitos and dulce de leche. (140, emphasis mine)

Of course that was not all the sugar was for. This conspicuous gap in the narrator's explanation points to the discrepancy between, on the one hand, the landlords' "cafecitos and dulce de leche", and, on the other, the huge international sugar dealings sustained by the migrants' fieldwork. Amabelle is obviously unaware of this broad economic and geopolitical context in which the genocide takes place, but her unawareness does not occur in a historical or discursive vacuum outside the intersecting chronopolitical dynamics within and beyond Hispaniola.

Against such dynamics, the unacknowledged imbrication between smallscale and largescale relations of power strategically brings the reader much closer to the naïve characterization of Amabelle than the colonialist presumption of the literate's superiority would normally allow. As these discourses of selfdisimplication parallel, reflect, and reinforce each other, they bring to the fore the immediate material context of relational suppression which Danticat's novel testimonio is in the actual process of incorporating and scrutinizing from within. Thus calling attention to the relations between suppressed historiography and colonial chronopolitics, Danticat's novel performs a shift from the eurocentric to the decolonial standpoint from which it may foreground "the conflictive imaginary that rises up with and from the colonial difference" (Mignolo, "Coloniality at Large" 22).

Danticat's novel testimonio thus incorporates and at the same time challenges the international gaze on 
what has been essentialized as the inherent instability and underdevelopment of the region. Significantly, it foregrounds rather than endorses Amabelle's denial of the "urgency of the situation," as her articulation of the event is already mediated by her relatively privileged position invested in downplaying the danger she and other Haitians face under Trujillo. Her denial of the impending genocide agonizes the reader as she repeatedly answers to Sebastien, Unèl, and Doctor Javier, who urge her to leave Alegría with them immediately, that the rumors of Trujillo's orders to kill all Haitians are "just talk" (125). Kongo later tells her that Sebastien and his sister had gone to the chapel to meet her so they could head for the border together-yet, perplexed, she gets delayed while, in her numbness, she is optimistic that they will still be there. When Kongo says he heard that Sebastien and Mimi had been taken away by army trucks, Amabelle's remark is that "[she] was not so ready to believe" (160).

In portraying Amabelle's disbelief, Danticat is offering not only a naïve characterization of her, but also a characterization of the unthinkable horror of racism. The narrator's numbness underscores her disidentification from the surreal horror which she refuses to associate with the dignity of the workers of the land-but also, yet covertly, with her own desire to remain in the comfort zone of the patriarchal stability afforded by her insertion within the Dominican household: "This could not touch people like me," Amabelle thinks, dispelling the "rumors" of the genocide. Strategically, her disidentification from the atrocity aligns her with the distant reader who also invests in perpetuating the normalized sense of mere spectatorship as if from outside the uncanny structures of horror which should-but, obviously now, do notremain in the past. This dynamic is a major effect and reactivation of chronopolitical mapping, which tends to naturalize the atrocity as pertaining essentially to the anachronic fabric of those who have been colonized and have not "moved on" from the past.

Both the narrator and the distant reader are thus invested in remaining in their comfort zones, under which their narrative urgency is overwritten. Therefore, when Amabelle finally decides to leave the
Dominican home where she has been raised, that is, when her disidentification from the atrocity no longer holds water, the reader's sense of his imbrication in the relations within which truth, authenticity, and history are chronopolitically defined is also shaken. No longer numb when Amabelle sets out to find Sebastien instead of remaining in the house or at the mill compound, the distant reader too can no longer wish (her) to stay in the comfort zone of Alegría.

Thus, while Amabelle's characterization seems to deflect the political aims of the testimonio narrative, it also engages the reader performatively with those aims, in the same breath. As it would not for Stoll in the context of the U.S.-backed dictatorship which had enforced the genocide in Guatemala, here the significance of whether the rumors of the genocide are true or not pales in the face of the urgency to dismantle its sanctioned structures. Still, the testimonio must contend with its own failure to overturn reified historiography, given the sedimented geocultural relations which it sets out to challenge.

As pointed out most resonantly by John Beverley (1993; 2004) and Gugelberger, ed. (1996), testimonio is a necessarily failed narrative whenever failure is defined by such values as canonization, consumption, and other forms of institutionalization which impinge on its ability to break through the reified reality it denounces. If, early on, the testimonio was understood to establish complicity with the readers by involving their heroic "identification-by engaging their sense of ethics and justice-with a popular cause normally distant, not to say alien, from their immediate experience" (Testimonio 37), now it also involves our disturbing dis/identification, resembling the "Yanki"-trained Haitian soldiers (Danticat 234) invested in not hearing their stories. This is clearly a welcome shift from a resolutionist aesthetic to one which performs what Linda Hutcheon (1989) calls complicitous critique-an ethical move towards repoliticizing dissent through the dismantling of master narratives and sovereign subject positionalities. ${ }^{21}$ In this light, while narrative agency is no doubt limited under colonialist power structures, its limitations also provide the sites or horizons for reconfiguring them. 
In this postmodern key, the reader's complicitous critique of the sanctioned structures of coloniality works to actualize their deconstruction. Proclaiming itself a "novel" on the cover, The Farming of Bones enacts the same deferral of testimonio as its narrator, but gains force increasingly as it builds awareness, as the next section should demonstrate, of the migrant differend-where the significance of the subaltern's voice is neutralized in the very act of narration.

\section{"In a language that is theirs, not yours": The Differend in the Migrant Text}

One of the most striking moments in the narrative is when it addresses the problem of how to get the survivor's testimonial to matter against its material and epistemic suppression. The question that emerges is, how can the migrant text reach an audience that is chronopolitically invested in reducing it to a remote past, a narrative of sole pathos and adversity, a particular reality pertaining to the geocultural margins alone? This question translates the roadblock around which the debate on the testimonio genre revolved resonantly after the publication of Stoll's and Arias's important volumes.

Engaging the terms of the testimonio controversy raised by Stoll while at the same time recentering Menchú's concern with the structures that sanction ongoing military intervention and genocide, Danticat's testimonio ensures a link between a determining moment in the Trujillo massacre-the moment often called the perejil-and the open question as to the reader's own stake in ending the colonialist reception of the migrant text. As explains Señora Valencia, "[the people's] own words reveal who belongs on what side" (Danticat 304). Only those who could produce the unmarked, hegemonic (Dominican) pronunciation of the Hispanic word perejil (meaning parsley), that is, without the French-inflected Haitian accent, were set free from torture by Trujillo's army. Those marked by the accent had "parsley stuffed into [their] mouths" by handfuls (193), and were then beaten by the Dominican soldiers. Only some of these were able to cross the river border near Dejabón into Haiti-Amabelle and Yves among them, both suffering significant physical, emotional and psychic damage for the rest of their lives. Most, however, were slaughtered or drowned as they tried to cross the river. In the novel, as in history, language is clearly a colonial device of biopolitical surveillance.

The Haitians' flight to the border thus emerges as the core of a broad geopolitical and historical context dictated by the pervasive fabrication of what JeanFrançois Lyotard has called the differend: "[a] case of differend between two parties takes place when the 'regulation' of the conflict that opposes them is done in the idiom of one of the parties while the wrong suffered by the other is not signified in that idiom." (Lyotard 2002, 11-13). This is precisely what is enacted throughout the novel, in at least three moments. First, when Amabelle hears about the danger, but is unalarmed-not because she can afford to be, but because she is numb to the violence which remains unsignified within the residence of Valencia and her baby, on whose every gesture Amabelle is bent, and Valencia's husband, the career-minded high officer who, as Danticat's reader knows by now, is no less than the commander-inchief of the genocide. Second, the differend also takes place, more explicitly in fact, when the migrants' idiom literally determines their death near the river border. Finally, and less explicitly, the differend is produced when the fabricated remoteness of the testimonio no longer holds water to the anglophone reader whose sanctioned ignorance is now at stake.

Many years after the perejil slaughter, when Amabelle has survived her derangement from trauma and returns to Valencia's estate near Alegría to mourn Sebastien at the waterfall (notice the representational shift whereby "moving on" follows from reconnecting with the past and engaging the facts of mourning), she recognizes in Valencia's current Haitian handmaid, Sylvie, the signs that she too was a survivor of the massacre: "Her voice squeaked one moment and was hoarse the next, as though she risked running out of breath at any time [...] When she stretched her neck, I saw that she had rope burns above her collarbone. They were even deeper and more pronounced than those on the woman at the border clinic, a deeply furrowed field" (292). Amabelle notices Sylvie's anxious frown as 
she "wiped her sweaty palms on her lap and tried to temper the audible racing of her breath." After Valencia probes Sylvie, asking whether she is ill, with difficulty the Haitian servant asks, "Why parsley?"

It is Valencia, however, who answers. Her reply to Sylvie's question underlines her sanctioned ignorance (much like that of Amabelle in the beginning of the novel, and possibly much like the reader's) of the horror inflicted upon the migrant population by her own husband, the high-rank officer Pico. Granting the dictator the title "Generalissimo" at every chance she gets, Valencia repeats as if by rote the division between "you" and "we" in the self-disimplicating tone of the anecdote. Valencia's reply to Sylvie is that in his youth Trujillo worked as a guard overseeing the Haitian fieldworkers and preventing their escape. As one of them tried to run away, Trujillo coerced him into revealing where he was, by promising that, in exchange, he would not shoot him. Valencia goes on to say that the fugitive

must not have trusted the Generalissimo, so he kept crawling, but he took the Generalissimo seriously enough to cry out the names of the fields as he passed through them. In the wheat, he called out 'twigo' for trigo. And in the parsley he said 'pewegil' for perejil. [...] Your people did not trill their $r$ the way we do, or pronounce the jota. 'You can never hide as long as there is parsley nearby', the Generalissimo is believed to have said. On this island, you walk too far and people speak a different language. Their own words reveal who belongs on what side. (304)

By contrast, Amabelle mentions "the easy word to say" (299): el corte, a familiar term for the gesture of sugar-cane cutting, but which replaces the migrants' working ethos with death. As Amabelle explains, Trujillo's army used farming machetes to make it look like the slaughter was a farmer-led fight (263). "El corte" is thus a colonial term for the slaughter, projecting it as a derivative of cross-border work-thus effectively blaming the victims in place of the criminals. The term, like the use of the farming machetes, furthermore reinforces the Nazi-modeled myth promoted by Trujillo "that it was a spontaneous outburst of anti-Haitian sentiments among the Dominican populace rather than a government- planned and strategically implemented act of genocide" aimed at exterminating Blacks before importing white males into the country (Rohrleitner 75-84). Countering this narrative, Danticat's testimonio, while "impl[ying] a reader presumed capable of responding, juridically or politically, to the urgency of the situation" (SaldañaPortillo 156), also implies the narrator's own capacity to privilege the urgency of her testimonio over its sanctioned neutralization in the comfort zone within the walls of the patriarchal household.

\section{Final remarks: “They ask you to bring proof”}

In his preface to Dominance without Hegemony: History and Power in Colonial India (1997), Ranajit Guha points out that the consideration of "history as writing" is crucial because "at a certain level the question of power in Colonial Asia or anywhere else in a land under foreign occupation can be phrased succinctly as 'Who writes the history of the subjugated people?"' (xiii). Gayatri Chakravorty Spivak had asked a somewhat different question in 1985: "Can the subaltern speak?”. Throughout her writings which argue for the relatively privileged subject's self-implication in epistemic violence in the production of knowledge, Spivak elaborates on the fact that subaltern speech is not lacking; rather, what is lacking is the sovereign subject's hearing, since the ability to speak is contingent on being heard: "no speech is speech if it is not heard. It is this act of hearing-to-respond that may be called the imperative to translate" ("Translation as Culture" 22).

Indeed, towards the end of the novel, Amabelle describes the evasion of hearing which produces the differend in the farse of national redemption negotiated between Haiti and the Dominican Republic under the Organization of American States. According to Danticat's partner in activism, former U.S. Attorney General Ramsey Clarke, " $\mathrm{t}]$ he Organization of American States interceded and forced the Dominican Republic to acknowledge 18,000 deaths for which it paid [US] $\$ 522,000$ in restitution with no other consequence than an angry neighbor. A Haitian life was worth $\$ 29$ to the OAS, with most lives unrecognized" (Haiti, online). Accordingly, Amabelle cites her friend Yves, who tells her that 
" $t \mathrm{t}$ here are officials of the state, justices of the peace who listen to those who survived the slaughter and write their stories down [...]. They ask you to bring papers. They ask you to bring proof." (Danticat 231)

Danticat need not have anticipated Stoll's arguments against Menchú's testimonio based on inaccurate evidence, because those arguments draw on a long history of sanctioned ignorance which produces the differend in torturous ways, for example by demanding "papers to show that all these people died" (234). Indeed, many survivors had learned that, even when their testimonios were supposedly "heard," their words reduced them to the differend: as when one of them says, "You testify, and then they retell your story in their way, in words that you will not understand, in a language that is theirs, not yours" (246).

Dictated from within the colonial differend, Amabelle's narrative of trauma is, as she says, "beyond healing" (199)-marked by a series of failed yet renewed attempts to be told: "I dream all the time of returning to give my testimony to the river, the waterfall, the justice of the peace, even to Generalissimo himself" (264). This is less a pathology to be ascribed to herself than to the conditions of narrative legibility and legitimacy, as Danticat's testimonio has made clear by now; the constant, urgent repetition of the attempt to speak is the symptom of the inability-which is not her own-"to tell the story and be heard, to in fact address the significance of her biography-to address [...] the suffering, the truth, and the necessity of this impossible narration-to a hearing 'you', and to a listening community" (Felman 1996, 45).

Unsurprisingly, by the end of the very first day, after hours of waiting in a crowd of over a thousand migrant workers at one of the many official posts throughout the country, Amabelle, Yves and others already know that they have been waiting in vain for their testimonials to be heard. As we learn from a woman who speaks to Amabelle,

"[the Justice of the Peace] writes your name in a book and then he says he will take your testimonio to President Vincent so you can receive the government's indemnization [...]. Then he lets you talk and he lets you cry and in the end he asks you if you have the documents that prove that what you said is really true, all those people you said you have lost." (234)

Thousands of migrants are subjected to the institutional enactment of hearing which only actualizes the trauma they have come to tell, for the Haitian soldiers of the Police Nationale, who wear "the same khaki uniforms as the Dominican soldiers-a common inheritance from their training during the Yanki invasion of the whole island" (234)-are merely pawns under the military regime. Eventually,

\begin{abstract}
[a]t dusk, the justice of the peace did not come out to speak to the crowd. The head sergeant came out instead and announced that there would be no more testimonials taken. All the money had already been distributed. The justice of the peace had already gone away when no one was looking, knowing we would be enraged if we saw him depart.
\end{abstract}

It took some time for people to take in what this meant. Their disappointment grew as the word spread from mouth to mouth and was reinterpreted by one person for the next. There were moans and screams of protests, convulsions and faintings as rocks began to fly. (235)

The differend is reinstalled, as the wrong suffered by Haitians is signified in the militarist key of the wrongdoers instead:

The people at the front of the crowd charged at the entrance. Trained by Yanki troops who were used to rebellious uprisings, the soldiers shot several rounds of bullets in the air.

A few of the soldiers were caught and passed from hand to hand as blows were struck, but the crowd was not really interested in them. The group charged the station looking for someone to write their names in a book, and take their story to President Vincent. They wanted a civilian face that would tell them that what they saw had indeed happened (235-36).

What I hope has become clear is the urgent parallel between the Haitian and the Guatemalan 
differends, urging the indictment of all genocides that remain ignored by the apparatuses of chronopolitical knowledge and power.

The connection Danticat ensures between the Haitian, Dominican and U.S. authorities has clearly been extended to Amabelle and her readers as well, so that her words implicate not only the "listener" within the novel but also the reader (outside?) in the ongoing suppression of decolonial historiography. In this light, Amabelle performs a complicitous critique of her own positionality under the privilege of the Dominican household invested in alienating the conflict; she thus draws a parallel with the contemporary alienation of the testimonio genre, and troubles its boundaries, making way for unpacking its ongoing relations with past and present-day genocides. Refocusing on historiography as a terrain of necessary decolonial contestation rather than feigned closure, Danticat's literary reworking of testimonio may thus decenter the ongoing deflection of attention from Menchús indictment of military intervention and genocide in the trivializing silencing which has followed in the aftermath of the testimonio controversy.

By exposing the suppressed relations that trouble chrononormative boundaries, Danticat's narrative performs a shift from a eurocentric to a decolonial standpoint which foregrounds "the conflictive imaginary that rises up and from the colonial difference" (Mignolo \& Ennis 2001, 42), dismantling the normative portrayal of the Trujillo genocide as pertaining to an obsolete past and to the geocultural margins alone. Bringing to the fore the "relations across time and between times" (Freeman 63) in which decolonial texts remain unheard, this queer chronopolitics works to unsettle anachronistic perceptions of the migrant text. It should also contribute to a reparative transgression of the chronopolitical boundaries that isolate the geocultural contexts in which genocides are imbricated, as well as the relations between past genocides and their contemporary legacies.

\section{Notes}

1. As María Lugones (2007) argues convincingly, the coloniality of power is defined in a masculinist key in Quijano 2000a and 2000b. Lugones claims that the coloniality of power is made up of the mututally imbricating systems of race, gender and sexuality. On the exclusion of gender and sexuality from Quijano's conception, which has framed mainstream discussions concerning the coloniality of power, see Lugones 2007. For a clarifying comment on this exclusion, itself constitutive of the coloniality of power, see Costa 2010.

2. On global coloniality, see Mignolo 2000 and Grosfoguel 2003, among others.

3. Elizabeth Freeman is here following McClintock 1995.

4. I understand the geocultural as an interface of subjectification, engendering situated and dynamic sets of chronopolitical values-but also, by the same token, the means to dismantle them from within the coloniality of power. Though Mignolo (2001) ascribes the decolonial conception of the geocultural to Aníbal Quijano and Immanuel Wallerstein (1992), the concept, though named otherwise, had been introduced a century earlier by José Martí in his influential Nuestra America (1891). Here, Martí called attention to the anglocentric valuesystems and networks of power standing ready to expand into the Caribbean, the Pacific, and Panama, and called for efforts to theorize and change the imaginings of global space relations from the standpoint of Latin American interests and perspectives.

5. For example, the U.S. occupation allowed the Haitian government to profit from the head tax charged from farm workers for the "right" to work across the border to find work (see Kaussen 2008). For relevant discussions of this inter-american context, see Castor 1974; Matibag, 2003; Renda 2001; Scott 2004; Smith 2009; Torres-Saillant 2006; Girard 2010; Tunzelmann 2011; Wiarda 1970; and Clarke et al. 1994 (co-edited and including a chapter by Danticat), among others.

6. Other novels on the Trujillo massacre include Alexis 1955; Castillo 1977; and Philoctète 2005 [1989]. Within her short "Afterword" to The Farming of Bones, Danticat acknowledges her precursor ("my manman, my muse") in telling the story of the genocide: "I do always remember that these stories-and all others-are yours to tell and not mine. To Jacques Stephen Alexis, for Compére Général Soleil" (312). Observing that U.S. violence against Haitians during U.S. occupation is a theme pervading Alexis's 1955 novel, Kaussen argues that "in Alexis's account, the heroic liberator of Europe is indeed the exterminator of blacks in the Caribbean." Kaussen adds that this account by which "the U.S. plays a double game: fighting against fascism abroad, it supports it in its own backyard" becomes even more disturbing in the context of the Haitian Revolution (1791-1804) as "the historical background for the struggle between European fascism and communism" (134-35).

7. Gayatri Chakravorty Spivak's term sanctioned ignorance refers to the normalized suppression of knowledges that 
do not confirm the neocolonial processes defining which perspectives are legitimate and which can be normatively ignored. (A Critique of Postcolonial Reason 337).

8. On the Haitian Revolution, see the influential rendition by James 1963 .

9. Shemak's mention of 20,000 Haitians is hypothetical. The fact that the number of persons murdered at the Massacre River is unknown (most accounts vary from 15,000 to 38,000 ) is in itself an index of the horror underlying the obliteration of history.

10. As Yúdice recalls, this point is made in the context of the testimonio genre: see Echevarría 1980.

11. See Bueno 1999 and Nance 2006.

12. For the classic example of such adherence, see D'Souza 1991. For other influential discussions of the canon wars which, unlike D'Souza's, put forth a favorable view of the canon's instability, see, for example, Bercovitch, ed. 1986; Lauter 1983; Guillory 1993; Wiegman and Pease, eds. 2002; and Bona and Maini, eds. 2006. In the context of testimonio, see Arias, ed. 2001; Pratt 2001; Gugelberger, ed. 1996; Berverley 2004.

13. See Stoll 1999. Excellent discussions of this controversy include Pratt 2001; Arias, ed. 2001; Arias 2007; and Klahn 2014. John Beverley's claim that "the issue'how outsiders were using Rigoberta's story to justify continuing a war at the expense of peasants who did not support it' (Stoll: 241)-is the main problem for Stoll, rather than the inaccuracies or omissions themselves" is questionable. Though Stoll's phrasing of the issue confirms "the sheer heterogeneity of decolonized space" differentiating subaltern positions from relatively privileged ones (Spivak, Critique of Postcolonial Reason 310), the claim is questionable in the face of Stoll's selection of (massive) arguments against Menchús text which do not converge with it. Curiously, Beverley also makes the point, on the same page, that

[w] hat seems to bother Stoll above all is that Menchú has an agenda. He wants her to be in effect a native informant who will lend herself to his purposes (of ethnographic information gathering and evaluation), but she is instead functioning in her narrative as an organic intellectual, concerned with producing a text of local history (sic) -that is, with elaborating hegemony. (2008 [2000] 576)

14. I borrow the term premature burial from the related context of the critique of the hegemonic notion of postfeminism as a prescription of feminism's death. See Hawkesworth 2004.

15. The title Against Literature encapsulates this view, elaborated extensively in Beverley 1993 and, later, extended in 2004. This critique had been made in Yúdice
1991, and was developed further in Gugelberger ed. 1996, among others.

16. The term genre trouble (McKenzie 1998) explores the implications and resonances of Judith Butler's theory of gender trouble, underlining the fact that, always already troubled, gender cannot be reduced to a so-called proper object supposedly circumscribed to a delimited field of power/knowledge.

17. See Gubelberger, ed. 1996; Arias, ed. 2001; and others.

18. I borrow the term literary can(n)on from Spivak ("Feminism and Critical Theory" 71).

19. According to Arias, "It is estimated that approximately 150,000 Mayas out of a total population of 5 million were massacred or disappeared during the peak of the conflict (1978-84)" (88).

20. In 1987, Laënnec Hurbon divided Haitian history into three periods: the long period of slavery (from the 16th century to the Haitian Revolution of 1804); Haitian independence (1804-1915); and American colonization, described as spanning from "1915 to [the] present" (74). Considering Haitian history from 1987 to this day, Hurbon's assertion remains sound. On the contrast between the historiographical fiction of Haiti and the fictionalized history of U.S. protectionism covering up contemporary U.S.-foreign policies in the region, see Rohrleitner, 2011.

21. Coined by Linda Hutcheon (1989) to articulate what she sees as the ethical move that politicizes postmodern texts, the phrase complicitous critique can be understood in terms of the Foucauldian notion of agency: in Judith Butler's terms,

[A] gency (...) will be directly counter to any notion of a voluntarist subject who exists quite apart from the regulatory norms which she/ he opposes. The paradox of subjectivation (assujetissement) is precisely that the subject who would resist such norms is itself enabled, if not produced, by such norms. Although this constitutive constraint does not foreclose the possibility of agency, it does locate agency as a reiterative or rearticulatory practice, immanent to power, and not a relation of external opposition to power.

(...)

[T] he "I" draws what is called its "agency" in part through being implicated in the very relations of power that it seeks to oppose. To be implicated in the relations of power, indeed, enabled by the relations of power that the "I" opposes is not, as a consequence, to be reducible to their existing forms. (Butler, Bodies that Matter 15; 123)

Therefore, complicitous critique is queerly compromised: "this is a strange kind of critique, one 
bound up ... with its own complicity with power and domination" (Hutcheon 4).

\section{Works Cited}

Alexis, Jacques Stephen. Compère Général Soleil. Paris: Gallimard, 1955. Trans. and intro. Carrol F. Charlottesville: The University Press of Virginia, 1999.

Alvarez, Julia. In the Time of the Butterflies. New York: Penguin, 1994.

Arias, Arturo. Taking Their Word: Literature and the Signs of Central America. Minnesota and London: Minneapolis University Press, 2007.

Arias, Arturo, ed. The Rigoberta Menchú Controversy. Minneapolis: University of Minnesota Press, 2001.

Barrios de Chungara, Domitila, and Moema Viezzer. Se me permiten hablar. México: Siglo XXI, 1977.

Bercovitch, Sacvan, ed. Reconstructing American Literary History. Cambridge: Harvard University Press, 1986.

Beverley, John. "Testimonio, Subalternity, and Narrative Authority" [2000]. A Companion to Latin American Literature and Culture. Ed. Sara Castro-Klaren. Malden and Oxford: Blackwell, 2008. 571-83.

. Testimonio: On the Politics of Truth. Minneapolis: University of Minnesota Press, 2004.

Against Literature. Minneapolis: University of Minnesota. Press, 1993.

Bona, Mary Jo, and Irma Maini, eds. Multiethnic Literature and the Canon Debates. Albany: State University of New York Press, 2006.

Bueno, Eva Paulino. "Carolina Maria de Jesus in the Context of Testimonios: Race, Sexuality, and Exclusion." Criticism. Wayne State University (Spring 1999): 257-84.

Butler, Judith. Bodies that Matter: On the Discursive Limits of 'Sex'. New York: Routledge, 1993.

Gender Trouble: Feminism and the Subversion of Identity. New York: Routledge, 1990.

Caminero-Santangelo, Marta. "At the Intersection of Trauma and Testimonio: Edwidge Danticat's The Farming of Bones." Antípodas: Journal of Hispanic and Galician Studies 20 (2009). http://www.antipodas.com. au. Accessed July 11, 2010.

Castillo, Freddy Prestol. El Masacre se pasa a pie. Santo Domingo: Ediciones de Taller, 1977.

Castor, Suzy. "The American Occupation of Haiti (19151934) and the Dominican Republic (1916-1924)." Massachusetts Review (Winter-Spring 1974): 253-74.
Christian, Barbara. "The Race for Theory." The Nature and Context of Minority Discourse. Special issue, ed. Abdul JanMohamed and David Lloyd. Cultural Critique 6 (Sprint 1987): 51-63.

Clarke, Ramsey et al., eds. Haiti: a Slave Revolution: 200 Years after 1804. New York: International Action Center, 1994. Web. 03 Sept. 2012.

Costa, Cláudia de Lima. "Feminismo, tradução cultural e a descolonização do saber." Fragmentos 39. Florianópolis, jul-dez 2010. p. 45-59.

Danticat, Edwidge. The Farming of Bones: A Novel. New York: Penguin, 1998.

Derrida, Jacques, and Avital Ronell. "The Law of Genre." Critical Inquiry 7.1 (Autumn 1980): 55-81.

D’Souza, Dinesh. "Travels with Rigoberta." Illiberal Education: The Politics of Race and Sex on Campus. New York: Free Press, 1991. 59-93.

Echevarría, Roberto González. "Biografía de un cimarrón and the Novel of the Cuban Revolution." Novel 13 (Spring 1980): 249-63.

Felman, Shoshana. "Education and Crisis, or the Vicissitudes of Teaching." Unclaimed Experience: Trauma, Narrative, and History. Ed. Cathy Caruth. Baltimore and London: The Johns Hopkins University Press, 1996 [1995]. 13-60.

Freeman, Elizabeth. “Time Binds, or, Erotohistoriography." Social Text 23.3-4 (Fall-Winter 2005): 57-68.

Girard, Philip. Haiti: The Tumultuous History: From Pearl of the Caribbean to Broken Nation. Macmillan, 2010.

Grosfoguel, Ramón. "The Epistemic Decolonial Turn: Beyond Political-Economy Paradigms." Cultural Studies 21.2/3 (March/May 2007)

Gugelberger, Georg. "Institutionalization of Transgression: Testimonial Discourse and Beyond." The Real Thing: Testimonial Discourse and Latin America. Ed. Georg Gugelberger. Durham: Duke University Press, 1996. 1-22.

Gugelberger, Georg, ed. The Real Thing: Testimonial Discourse and Latin America. Ed. Georg Gugelberger. Durham: Duke University Press, 1996.

Guillory, John. Cultural Capital: The Problem of Literary Canon Formation. Chicago: The University of Chicago Press, 1993.

Hawkesworth, Mary. "The Semiotics of Premature Burial: Feminism in a Postfeminist Age." Signs: Journal of Women in Culture \& Society 29.4 (Summer 2004): 961-85.

Huggan, Graham. The Postcolonial Exotic: Marketing the Margins. New York: Routledge, 2001. 
Hurbon, Laënnec. Comprendre Haïti: Essai sur létat, la nation, la culture. Paris: Karthala, 1987.

Hutcheon, Linda. The Politics of Postmodernism. London and New York: Routledge, 1989.

Ink, Lynn Chun. "Remaking Identity, Unmaking Nation: Historical Recovery and the Reconstruction of Community in In the Time of the Butterflies and The Farming of Bones. Callaloo, 27.3 (Summer, 2004): 788807.

James, C.L.R. The Black Jacobins: Toussaint L'Ouverture and the San Domingo Revolution. Random House, 1963.

Jesus, Carolina Maria de. Quarto de Despejo. São Paulo: Livraria Francisco Alves, 1960.

Kaussen, Valerie. Migrant Revolutions: Haitian Literature, Globalization, and U.S. Imperialism. Lanham: Rowman \& Littleman, 2008.

Klahn, Norma. “Locating Women's Writing and Translation in the Americas in the Age of Latinamericanismo and Globalization". Translocalities/Translocalidades: Feminist Politics of Translation in the Latin/a Americas. Ed. Sonia E. Alvarez, Cláudia de Lima Costa, Verónica Feliu, Rebecca J. Hester, Norma Klahn, and Millie Thayer, with Cruz Caridad Bueno. Durham: Duke University Press, 2014. 39-56.

Lauter, Paul. Reconstructing American Literature: Courses, Syllabi, Issues. Old Westbury: The Feminist Press, 1983.

Lugones, María. "Heterosexualism and the Colonial Modern Gender System.” Hypatia, 22.1 (Winter 2007): 186-209.

Lyotard, Jean-François. The Differend: Phrases in Dispute. Minneapolis: University of Minnesota Press, 2002.

Maldonado-Torres, Nelson. "On the Coloniality of Being: Contributions to the Development of a Concept." Cultural Studies 21.2/3 (March/May 2007): 240-70.

Martí, José. Nuestra América. Buenos Aires: Editorial Losada, 1939.

Matibag, Eugenio. Haitian-Dominican Counterpoint: Nation, State, and Race on Hispaniola. New York: Palgrave, 2003.

McClintock, Anne. Imperial Leather: Race, Gender, and Sexuality in the Colonial Contest. New York and London: Routledge, 1995.

McKenzie, Jon. "Genre Trouble: (The) Butler Did It." The Ends of Performance. Ed. Peggy Phelan and Jill Lane. New York and London: New York University Press, 1998. 217-35.

Menchú, Rigoberta, and Elizabeth Burgos-Debray. Me Llamo Rigoberta Menchú e así me Nació da Conciencia.
Mexico: Siglo Veintiuno Editores; Havana: Casa de Las Americas, 1985 [1983].

I, Rigoberta Menchú: An Indian Woman in Guatemala. Trans. Ann Wright. London: Verso, 1984.

Mignolo, Walter D. Local Histories / Global Designs: Coloniality, Subaltern Knowledges, and Border Thinking. Princeton: Princeton University Press, 2000.

Mignolo, Walter D., and Michael Ennis. "Coloniality at Large: The Western Hemisphere in the Colonial Horizon of Modernity". Trans. Michael. Ennis. The New Centennial Review 1.2 (Fall 2001): 19-54.

Misrahi-Barak, Judith. "Exploring Trauma through the Memory of Text: Edwidge Danticat Listens to Jacques Stephen Alexis, Rita Dove, and René Philoctète." Journal of Haitian Studies, 19.1 (Spring 2013): 163-83.

Montejo, Esteban, and Miguel Barnet. Biografía de un cimarrón. Buenos Aires: Editorial Galerna, 1966.

Nance, Kimberley A. Can Literature Promote Justice? Trauma Narrative and Social Action in Latin American Testimonio. Nashville: Vanderbilt University Press, 2006.

Philoctète, René. Massacre River. Trans. Linda Coverdale. New York: New Directions, 2005 [Le peuple des terres mêlées, 1989].

Pratt, Mary Louuise. "I, Rigoberta Menchú and the 'Culture Wars"'. The Rigoberta Menchú Controversy. Ed. Arturo Arias. Minneapolis: University of Minnesota Press, 2001. 29-57.

Quijano, Anibal. "Coloniality of Power, Eurocentrism, and Latin America." Nepantla: Views from South 1.3 (2000a): 533-80.

"Colonialidade del Poder y Clasificacion Social." Festschrift for Immanuel Wallerstein. Special issue, Journal of World Systems Research 5.2 (Summer/Fall): 2000b. 93-126.

Quijano, Aníbal and Immanuel Wallerstein. "Americanity as a Concept, or the Americas in the Modern WorldSystem." International Social Sciences Journal, 134 (1992): 549-57.

Renda, Mary. Taking Haiti: Military Occupation \& the Culture of U.S. Imperialism, 1915-1940. Chapel Hill and London: The University of North Carolina Press, 2001.

Rohrleitner, Marion Christina. “Breaking the Silence': Testimonio, Revisionary Historiography, and Survivor's Guilt in Edwidge Danticat's The Farming of Bones and The Dew Breaker." Interdisciplinary Humanities 28.1 (2011): 73-85. 
Saldaña-Portillo, María Josefina. The Revolutionary Imagination in the Americas and the Age of Development. Durham: Duke University Press, 2003.

Sanjínes C., Javier. "Beyond Testimonial Discourse: New Popular Trends in Bolivia”. The Real Thing: Testimonial Discourse and Latin America. Ed. Georg Gugelberger. Durham: Duke University Press, 1996. 254-65.

Scott, Helen. "200 Years of U.S. Imperialism: Haiti Under Siege. International Socialit Review, 35 (May-June 2004). Web. 09 Oct., 2013.

Segura-Rico, Nereida. "Witnessing History: Metatestimonio in Literary Representations of the Trujillo Dictatorship." Antipodas: Journal of Hispanic and Galician Studies, 20 (2009). http://www.antipodas. com.au. Accessed July 11, 2010.

Sesnik, Jelena. "Wounded History: A Reading of Edwidge Danticat's Fiction." Studia Romanica et Anglica Zagrabiensia, LI (2006): 231-60.

Shemak, April. "Re-Membering Hispaniola: Edwidge Danticat's The Farming of Bones." Modern Fiction Studies 48.1 (Spring 2002): 83-112.

Smith, Matthew J. Red and Black in Haiti: Radicalism, Conflict, and Political Change, 1934-1957. Chapel Hill: The University of North Carolina Press, 2009.

Spivak, Gayatri Chakravorty. "Translation as Culture." Parallax, 6.1 (2000): 13-24.

A Critique of Postcolonial Reason: Towards a History of the Vanishing Present. Cambridge: Harvard University Press, 1999.

"Feminism and Critical Theory." The Spivak Reader. Ed. Donna Landry and Gerald MacLean. New York and London: Routledge, 1996. 53-74.

“Translator's Preface." Of Grammatology. Jacques Derrida. Trans. Gayatri Chakravorty Spivak. Baltimore: The Johns Hopkins University Press, 1998 [1976]. ix-lxxxvii.

Stoll, David. Rigoberta Menchu and the Story of All Poor Guatemalans. Boulder: Westview Press, 1999.

Tegmark, Mats. "Studying Fictional Representations of History in the L2 Classroom. L2 Journal, 4.1 (2012). Web. 26 Sept., 2013.

Torres-Saillant, Silvio. An Intellectual History of the Caribbean. New York: Palgrave Macmillan, 2006.

Trouillot, Michel-Rolph. Silencing the Past: Power and the Production of History. Boston: Beacon Press, 1995.

Tunzelmann, Alex von. Red Heat: Conspiracy, Murder, and the Cold War in the Caribbean. New York: Henry Hold and Co., 2011.
Unnold, Yvonne S. "Narratives of Trauma from the Southern Cone." Latin American Narratives and Cultural Identity. Ed. Irene Maria F. Blayer and Mark Cronlund Anderson. New York: Peter Lang, 2004. 7593.

Wiarda, Howard J. Dictatorship and Development: The Methods of Control in Trujillo's Dominican Republic. Gainesville: University of Florida Press, 1970.

Wiegman, Robyn, and Donald E. Pease Jr., eds. The Futures of American Studies. Durham: Duke University Press, 2002.

Yúdice, George. “Testimonio and Postmodernism.” Latin American Perspectives 70, 18.3 (Summer 1991): 15-31.

Recebido em: 26/05/2014 Aceito em: 27/06/2014 
